DOI 10.18551/rjoas.2019-02.29

\title{
FACTORS THAT INFLUENCE THE PRODUCTION RISK OF WHITE PEPPER IN BANGKA BELITUNG PROVINCE, INDONESIA
}

\author{
Pranoto Yudi Sapta*, Purwasih Rati \\ Department of Agribusiness, Faculty of Agriculture, Fisheries and Biology, \\ Bangka Belitung University, Indonesia \\ *E-mail: udhei sapta@yahoo.com
}

\begin{abstract}
This research was conducted to analyze the factors that influence the risk of white pepper production in the Bangka Belitung Archipelago Province. The study was conducted in South Bangka Regency, Belitung Regency, and West Bangka Regency from January 2018 to October 2018. The research method used was the survey method and the sampling method used was purposive sampling. The number of farmers used as respondents was 120 people. The factors that influence the risk of white pepper production are analyzed using a model developed by Just and Pope (1979). The results showed that the factors affecting the risk of white pepper production in the Province of Bangka Belitung Archipelago were labor and lime, both of which were risk reducing.
\end{abstract}

\section{KEY WORDS}

White pepper, production, risk, risk reducing.

According to historical records, pepper commodities became one of the attractions of Europeans to come to Indonesia. The spices were growing rapidly since the Netherlands through the VOC opened a trading office in Palembang which also covered the Bangka Belitung region. Since three centuries ago, Bangka pepper was better known internationally as Muntok White Pepper. The name Muntok refers to the name of the port which now includes the area of West Bangka Regency which is a transit area for pepper trading from the Bangka Belitung region to the outside world. Pepper is a plant that was once a prime commodity on the islands of Bangka and Belitung. It can be seen that many people have increased their welfare due to pepper farming. In addition, plants that have been cultivated in Indonesia since the colonial era have also made the name Bangka Belitung Archipelago known to foreign countries (LPPM UBB 2015).

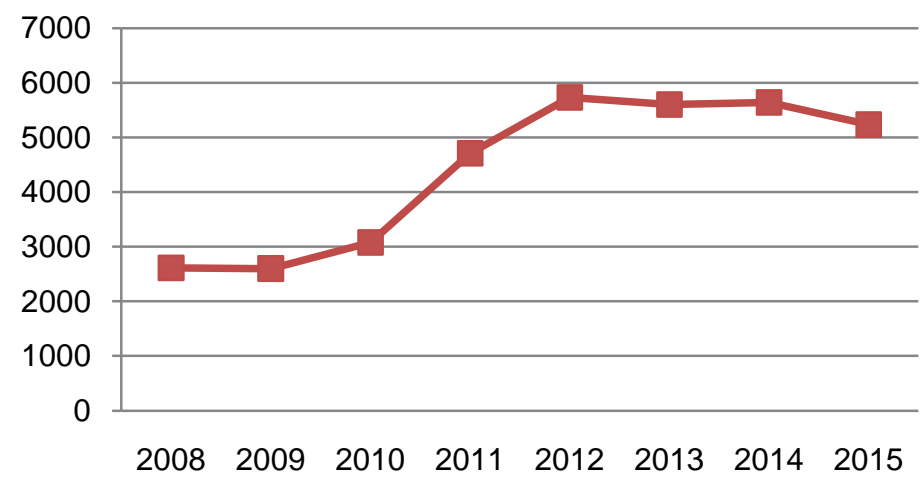

Figure 1 - Average Pepper Production in Bangka Islands Production Belitung

Based on data from the BPS Province of Bangka Belitung Islands (2016) that the average white pepper production in the Bangka Belitung Archipelago Province from 2008 to 2015 was 26,400 tons, of which South Bangka Regency contributed 45.66 percent (12,055 tons), Belitung Regency contributed 18,41 percent (4,859 tons), and West Bangka Regency accounted for 14.36 percent $(3,791$ tons). Thus, the district that contributes the largest 
pepper production in the Bangka Belitung Archipelago Province from 2008 to 2015 is South Bangka Regency, Belitung Regency and West Bangka Regency. The following in Figure 1 presents the average pepper production in the Bangka Belitung Archipelago Province from 2008 to 2015.

Although the three regencies such as South Bangka, Belitung and West Bangka have the largest pepper production in the Bangka Belitung Archipelago Province, pepper production in the district from 2012 to 2015 has fluctuated. Fluctuating production can be caused by several factors including erratic weather and pest and plant disease attacks. Fluctuating pepper production indicates that the management of pepper farming is influenced by the risk of production.

Research on the risk of white pepper production has been carried out by Jamilah (2016), namely in Bakam Village, Bakam District, Bakam Regency. The risk of white pepper production was analyzed using the GARCH model, where the factors thought to affect the risk of white pepper production were lime, Urea fertilizer, TSP fertilizer, KCL fertilizer, NPK fertilizer, pesticides, and labor. Therefore, the purpose of this research is to analyze the factors that influence the risk of white pepper production in Bangka Belitung Archipelago Province.

\section{METHODS OF RESEARCH}

This research was conducted in three districts in the Bangka Belitung Islands Province which included South Bangka Regency, Belitung Regency, and West Bangka Regency. This was done with the consideration that the three districts had higher pepper production than other districts and their production had fluctuated from year to year. This research was conducted from January 2018 to October 2018.

The research method used in this study is the survey method. This research uses purposive sampling withdrawal method. The criteria for farmers who will become respondents are farmers who plant white pepper at least 2 times harvesting and the minimum number of trees is 1,000 stems. The number of farmers who will be used as respondents can be seen in Table 1.

Table 1 - Number of Farmer Respondents

\begin{tabular}{lll}
\hline No & District/City & Number of Farmers (people) \\
\hline 1 & Bangka Selatan & 40 \\
2 & Belitung & 40 \\
3 & Bangka Barat & 40 \\
\hline
\end{tabular}

Factors that influence the risk of white pepper production are analyzed using a model developed by Just and Pope (1979). This model accommodates the existence of production risks by incorporating variance from the production equation. The model is as follows:

$$
q=f(x)+g(x) \varepsilon
$$

Where: $\mathrm{Q}=$ Amount of production achieved; $\mathrm{f}(\mathrm{x})=$ Production function; $\mathrm{g}(\mathrm{x})$ = Production risk function; $X=$ Production factor; $E=$ Error term.

Production function:

$$
f(x)=\operatorname{LnY} i=\beta_{0}+\beta_{1} \operatorname{Ln} X_{1}+\beta_{2} \operatorname{Ln} X_{2}+\beta_{3} \operatorname{Ln} X_{3}+\beta_{4} \operatorname{Ln} X_{4}+\beta_{5} D_{1}+\beta_{6} D_{2}+\varepsilon
$$

Production Variants:

$$
\sigma_{Y_{1}}=\left(Y_{i}-\hat{Y}_{i}\right)^{2}
$$


Production risk function:

$$
g(x)=\operatorname{Ln} \sigma_{Y_{i}}^{2}=\alpha_{0}+\alpha_{1} \operatorname{Ln} X_{1}+\alpha_{2} \operatorname{Ln} X_{2}+\alpha_{3} \operatorname{Ln} X_{3}+\alpha_{4} \operatorname{Ln} X_{4}+\alpha_{5} D_{1}+\alpha_{6} D_{2}+\varepsilon
$$

Where: $\mathrm{Y}=$ White pepper production $(\mathrm{kg} / \mathrm{stem}) ; \hat{Y}_{i}=$ Suspected white pepper production based on model $(\mathrm{kg} / \mathrm{stem}) ; \mathrm{B}=$ Parameters estimated in the production function; $A=$ Parameters estimated in the production risk function; $X_{1}=$ Fertilizer $N(\mathrm{~kg} / \mathrm{stem})$; $\mathrm{X}_{2}=$ Fertilizer $\mathrm{P}(\mathrm{kg} / \mathrm{stem}) ; \mathrm{X}_{3}=$ Fertilizer $\mathrm{K}(\mathrm{kg} / \mathrm{stem}) ; \mathrm{X}_{4}=$ Labor $(\mathrm{HOK} / \mathrm{stem}) ;$ $D_{1}=$ Dummy lime, $1=$ give and $0=$ not give; $D_{2}=$ Dummy pesticide administration, $1=$ giving and $0=$ not giving; $E=$ Error term .

\section{RESULTS AND DISCUSSION}

Respondents in this study were the ones who cultivated white pepper plants. The respondents' identity included age, education level, farming experience, and number of dependents in the family. Residents are said to have a productive age if they are in the range of 15-64 years and are said to have a non-productive age if they are less than 15 years and 65 years and over (BPS RI 2016). The age distribution of respondents of white pepper farming in Bangka Belitung Province can be seen in Table 2.

Table 2 - Identity of Respondents by Age in the Bangka Belitung Province in 2018

\begin{tabular}{llll}
\hline No & Age (year) & Number (people) & Percentage $(\%)$ \\
\hline 1 & $16-23$ & 3 & 2,50 \\
2 & $24-31$ & 14 & 11,67 \\
3 & $32-39$ & 22 & 18,33 \\
4 & $40-47$ & 35 & 29,17 \\
5 & $48-55$ & 21 & 17,50 \\
6 & $56-62$ & 14 & 11,67 \\
7 & $63-70$ & 9 & 7,50 \\
8 & $71-78$ & 2 & 1,67 \\
\hline
\end{tabular}

Source: Processed Primary Data, 2018.

Based on Table 2, it indicates that all respondents are in the productive age group. The highest percentage in the age group 40 - 47 years is 35 people or 29.17 percent, while the least is in the age group 71-78 years with 2 people or 1.67 percent. Respondents who are in the productive age group make it possible to increase the production of white pepper. This was seen from the strength and physicality of respondents who were still strong in managing white pepper farming.

Education level is an important factor for knowing the level of human resources. The level of education in this study illustrates the state of education of respondents in Bangka Belitung Province. According to Mosher (1981) education has an important role in business productivity and is a facilitating factor for agricultural development, because with education farmers recognize knowledge, skills and new ways of doing farming activities. The education level of white pepper respondents in Bangka Belitung Province can be seen in Table 3.

In general, farmers who were the respondents in this study had low levels of education. This could be seen from the percentage of respondents' education level as depicted in Table 3. Most of the white pepper respondents in Bangka Belitung Province studied only up to the elementary school level with 41 people or 34.17 percent. Meanwhile, the level of senior secondary education was 39 people or 32.50 percent and tertiary education was only 9 people or 7.5 percent of the total pepper respondents in Bangka Belitung Province.

Based on the results of interviews in the field, the low level of education of respondents was due to the limited cost of their parents to provide high education so that respondents were taught to live independently by following the footsteps of their parents becoming farmers, especially white pepper farmers. The low level of education of these respondents 
massively affected the absorption of new innovations in white pepper cultivation in accordance with the recommendations. Even though they were given counseling and training on white pepper cultivation, most of the respondents found it difficult to follow and they continued to maintain the cultivation techniques carried out from generation to generation.

Table 3 - Identity of Respondents by Education Level in Bangka Belitung Province in 2018

\begin{tabular}{llll}
\hline Number & Education level & Number (people) & Percentage (\%) \\
\hline 1 & Not Graduating From School & 13 & 10,83 \\
2 & Elementary School Graduates & 41 & 34,17 \\
3 & Junior High School Graduates & 18 & 15,00 \\
4 & Senior High School Graduates & 39 & 32,50 \\
5 & University Graduates & 9 & 7,50 \\
\hline Total & & 120 & 100,00 \\
\hline
\end{tabular}

Source: Processed Primary Data, 2018.

The respondents who have higher levels of education will be very responsive to information and new innovations about white pepper cultivation in accordance with the recommendations. In addition to formal education, there are also non-formal education such as activities or learning from agricultural extension workers and the Integrated Pest Management Field School (SL-IPM) by the government.

Farming experience is one of the factors that influence success in the plantation sector, especially white pepper farming. The respondents learned from experience so that they gained knowledge to expedite their farming activities or improve the cultivation system. The experience referred to in this study is the length of time the respondents did white pepper farming. In general the respondent farmers did white pepper farming for generations, so that they had a long experience. The experience of white pepper farming of respondents in Bangka Belitung Province can be seen in Table 4.

Table 4 - Identity of Respondents Based on Farming Experience in Bangka Belitung Province

\begin{tabular}{llll}
\hline Number & Farming Time (Year) & Number (people) & Percentage (\%) \\
\hline 1 & $<10$ & 41 & 34,17 \\
2 & $11-25$ & 54 & 45,00 \\
3 & $26-41$ & 22 & 18,33 \\
4 & $>42$ & 3 & 2,5 \\
\hline Total & & 120 & 100,00 \\
\hline
\end{tabular}

Based on Table 4, white pepper farmers in Bangka Belitung Province who were chosen as the respondents in this study were farmers who had long been doing white pepper farming. Most respondents have experienced between 11 and 25 years, which is equal to 45 percent of the respondents of white pepper as a whole. The experience of farming respondents starting from the bottom is starting from farm laborers to owning land privately, thus their knowledge of how to cultivate white pepper is quite high. But in the current conditions, the cultivation they did from the past was not so good anymore to be applied. This is due to the soil conditions that have been repeatedly processed for agricultural land which causes pests and diseases to attack white pepper plants are increasing, so the respondents must have broader knowledge to eradicate pests and diseases, and cultivate white pepper as recommended.

The number of family dependents is one measurement that describes the economic burden which must be borne by the respondents' farmers. The more the number of people in the family, the heavier the burden must be borne. The number of family dependents will be a benchmark for the family head to work harder to fulfill the family's needs. The number of dependents of respondents who are the source of research is described in Table 5.

Based on Table 5, when viewed from the number of family dependents, there are 33.3 percent or 40 respondents who have a family of 4 people. This illustrates that the white pepper respondents in Bangka Belitung Province are quite aware that with a small family size will reduce the economic burden for respondents and the number of dependents is at 
least 0 and 1 at 1.6 and 3.33 percent. The number of family dependents causes a small number of workers in the family who will help work in the field, so they have to hire workers outside the family.

Table 5 - Identity of Respondents Based on Number of Family Dependents in Bangka Belitung Province in 2018

\begin{tabular}{llll}
\hline Number & Interval Number of Dependents (People) & Number (people) & Percentage (\%) \\
\hline 1 & 0 & 2 & 1,67 \\
2 & 1 & 4 & 3,33 \\
3 & 2 & 11 & 9,17 \\
4 & 3 & 25 & 20,83 \\
5 & 4 & 40 & 33,33 \\
6 & 5 & 24 & 20,00 \\
7 & 6 & 8 & 6,67 \\
8 & 7 & 6 & 5,00 \\
\hline Total & & 120 & 100,00 \\
\hline
\end{tabular}

Source: Processed Primary Data, 2018.

Analysis of factors that influence production is suspected using the production function. The production function is obtained by registering the dependent variable with an independent variable. The dependent variable in this study is white pepper production in the Bangka Belitung Archipelago Province. The independent variables in this study were $\mathrm{N}$ fertilizer, $\mathrm{P}$ fertilizer, $\mathrm{K}$ fertilizer, labor, lime dummy, and dummy pesticide administration. The results of estimating the production function and the risk function of white pepper production can be seen in Table 6 .

Table 6 - Results of Estimated Production Function and Risk Function of White Pepper Production in the Province of Bangka Belitung Archipelago

\begin{tabular}{|c|c|c|c|c|}
\hline Variable & Coefficient & Std. Error & $\mathrm{T}$ & Sig. \\
\hline (Constant) & 2,967 & 0,546 & 5,435 & 0,000 \\
\hline Ln fertilizer $\mathrm{N}$ & 0,130 & 0,122 & 1,065 & 0,289 \\
\hline Ln fertilizer $P$ & $-0,058$ & 0,110 & $-0,529$ & 0,598 \\
\hline Ln fertilizer $\mathrm{K}$ & 0,232 & 0,106 & 2,193 & 0,031 \\
\hline Ln labor & 0,260 & 0,086 & 3,039 & 0,003 \\
\hline Dummy limestone & $-0,020$ & 0,168 & $-0,119$ & 0,906 \\
\hline Dummy pesticide & 0,135 & 0,205 & 0,657 & 0,513 \\
\hline \multicolumn{5}{|l|}{$R^{2}=0,249$} \\
\hline (Constant) & 0,376 & 0,182 & 2,062 & 0,042 \\
\hline $\operatorname{Ln} X 11$ & 0,043 & 0,074 & 0,584 & 0,561 \\
\hline $\operatorname{Ln} \times 21$ & 0,022 & 0,064 & 0,351 & 0,726 \\
\hline LnX31 & 0,030 & 0,065 & 0,457 & 0,649 \\
\hline $\operatorname{LnX} 41$ & $-0,132$ & 0,061 & $-2,148$ & 0,034 \\
\hline Dummy limestone & $-0,115$ & 0,051 & $-2,256$ & 0,026 \\
\hline Dummy pesticide & $-0,076$ & 0,065 & $-1,172$ & 0,244 \\
\hline
\end{tabular}

Based on Table 6, it obtained the value of the coefficient of determination (R square) of 0.249 . This value is quite representative because of the 6 variables analyzed, there are 2 variables that have a significant effect on the production of white pepper. This value indicates that 24.9 percent of the variation in white pepper production in the Province of Bangka Belitung Archipelago can be explained by $\mathrm{N}$ fertilizer, $\mathrm{P}$ fertilizer, $\mathrm{K}$ fertilizer, labor, lime dummy, and dummy pesticide administration, while the remaining 75.1 percent explained by other variables outside the model. Variables that significantly affect the production of white pepper are $\mathrm{K}$ fertilizer and labor. $\mathrm{K}$ fertilizer variable has a significant effect on the 5 percent level with a regression coefficient of 0.232 . This value indicates that if an increase in the amount of $\mathrm{K}$ fertilizer (other inputs are considered constant), it can still increase the production of white pepper. In addition, labor also has a significant positive effect on white pepper production at a real level of 1 percent. The regression coefficient of labor is equal to 0.26 . This value also indicates that if an increase in the number of workers (other inputs are considered constant), then it can still increase the production of white pepper. $\mathrm{N}$ fertilizer, $\mathrm{P}$ 
fertilizer, lime dummy, and dummy pesticide administration did not significantly affect the level of 10 percent.

The coefficient of determination obtained from estimating the production risk function is 0.12 . This value is also quite representative in explaining the variation of white pepper production because of the 6 variables analyzed, there are only 2 variables that significantly affect the risk of white pepper production in the Bangka Belitung Archipelago Province. This value of the coefficient of determination is quite low but in line with the results of Jamilah (2016). Variables that have no significant effect on the risk of production is white $\mathrm{N}$ fertilizer, $\mathrm{P}$ fertilizer, $\mathrm{K}$ fertilizer, and dummy pesticide. This is in line with the results of Jamilah's research (2016) that Urea, TSP, and NPK fertilizers do not affect the risk of white pepper production.

Variables that have a significant effect on the risk of white pepper production are labor and lime. In the production risk function, labor is said to be risk reducing because the regression coefficient value obtained is negative which is equal to -0.132 and its value is significant. Risk reducing shows that the use of labor can reduce the risk of white pepper production or production variations achieved. Variations in production achieved or production risks can be reduced if the workforce is able to manage white pepper farming well. Based on the characteristics of the respondents, most of the respondents had experienced between 11 and 25 years, namely as many as 45 percent of the respondents of white pepper as a whole. The experience of respondents in farming started from below, starting from being a farm worker to finally owning land privately, thus their knowledge of how to cultivate white pepper is quite high. The results of this study are in line with the results of Jamilah's research (2016) that labor is a factor of production that can reduce the risk of white pepper production.

In addition, the chalk dummy variable also has a significant effect on the risk of white pepper production and the regression coefficient value is -0.115 . This value shows that lime can be said to be risk reducing which means that lime can reduce the risk of production or variations in white pepper production achieved. If the administration of lime is done well, the production variation achieved or the risk of producing white pepper can be reduced. This is in line with the results of Jamilah (2016) study that lime is a production factor that can reduce the risk of white pepper production.

\section{CONCLUSION}

The factors that influence the risk of white pepper production in the Province of Bangka Belitung Archipelago are labor and lime, where both are risk reducing. Meanwhile, fertilizers containing $\mathrm{N}$ elements, fertilizers containing $\mathrm{P}$ elements, lime dummy, and dummy pesticides did not significantly affect the risk of white pepper production in the Bangka Belitung Islands Province.

\section{REFERENCES}

1. Mosher A.T. 1981. Menggerakkan and Membangun Pertanian. Jakarta (ID): Yasaguna.

2. [BPS] Badan Pusat Statistik Provinsi Kepulauan Bangka Belitung. 2016. Produksi Lada Menurut Kabupaten/Kota. Provinsi Kepulauan Bangka Belitung (ID): Badan Pusat Statistik Provinsi Kepulauan Bangka Belitung.

3. [BPS RI] Badan Pusat Statistik Republik Indonesia. 2016. Profil Penduduk Indonesia Hasil Supas 2015. Jakarta (ID): Badan Pusat Statistik Republik Indonesia.

4. Jamilah. 2016. Analisis Risiko Produksi Usahatani Lada Putih di Desa Bakam. Kecamatan Bangka Kabupaten Bangka. Balunijuk (ID): Perikanan, and Biologi.

5. Just RE, Pope RD. 1979. On the Relationship of Input Decisions and Risk. In: Roumasset, J.A, J.M. Boussard and I. Shing (Eds). Risk, Uncertainly and Agricultural Development. New York (US): Agricultural Development Council.

6. LPPM Universitas Bangka Belitung. 2015. Kajian Model Pembiayaan and Komoditas Lada Di Provinsi Kepulauan Bangka Belitung. Provinsi Kepulauan Babel. 